\title{
Zabawowe sposoby wprowadzania zapisu muzycznego w zakresie wysokości dźwięku - propozycje dla nauczycieli klas I-III
}

\begin{abstract}
Gamed introducing of musical notation in terms of pitch - suggestions for 1-3 grades teachers

Introduction of the musical alphabet is an important moment in children's music education. The main aims of this paper are to remind teachers of two ways of recording pitch, outline teaching guidelines as proposed by psychologists and present some methods of introducing musical notation adjusted to early school children abilities.
\end{abstract}

Keywords: games with music, games with Boom whackers, musical notation, preschool and early school education, suggestions for teachers, musical games, solmization, musical alphabet, music education, music theory for children

Słowa kluczowe: zabawy z muzyką, zabawy z Bum Bum Rurkami, zapis muzyczny, pedagogika przedszkolna i wczesnoszkolna, propozycje dla nauczycieli, zabawy muzyczne, solmizacja, alfabet muzyczny, edukacja muzyczna, teoria muzyki dla dzieci

Zapis muzyczny stanowi istotne zagadnienie $\mathrm{w}$ kształceniu przygotowującym uczniów do uczestnictwa w kulturze muzycznej. Z tego względu niniejszy artykuł ma na celu przybliżenie nauczycielom dwóch sposobów zapisu wysokości dźwięku, opisanie wskazówek dotyczących uczenia formułowanych przez psychologów i zaprezentowanie wybranych sposobów wprowadzania zapisu muzycznego w sposób dostosowany do możliwości dzieci w wieku wczesnoszkolnym. 


\title{
Dwa sposoby zapisu wysokości dźwięku
}

Ważnym osiągnięciem kultury stało się wynalezienie notacji muzycznej. Przez notację muzyczną najogólniej rozumie się „system znaków pisanych odzwierciedlających konstrukcję dzieła muzycznego i umożliwiających jego zapisanie i odtworzenie" (Mała encyklopedia muzyki, 1968, s. 707). Jej współczesny kształt jest wynikiem wielowiekowych poszukiwań, mających na celu utrwalanie ulotnych przebiegów dźwiękowych, tak aby były dostępne dla szerokich kręgów odbiorców i dla kolejnych pokoleń. Szczególne osiągnięcia w tym zakresie miał Guido z Arezzo. J. A. Sloboda pisze:

\begin{abstract}
Poza udoskonaleniem systemu czteroliniowego Guidonowi zawdzięczamy także stworzenie systemu sylab mnemonicznych - solmizacji „sol fa” dla śpiewaków. Jest to sposób zapamiętywania relacji wysokościowych pomiędzy dźwiękami na pięciolinii przez odniesienie do dźwięków dobrze znanej melodii. Melodią, którą wybrał, był hymn ku czci św. Jana Chrzciciela Ut queant laxis. Śpiew ten „rozpisuje” na sześciodźwiękową skalę $u t, r e, m i$, $f a$, sol, la. System solmizacji z niewielkimi poprawkami jest wciąż używany, choć archaiczne Ut queant laxis zastąpione zostało bardziej stosownymi współczesnymi pieśniami (jak uwiecznione w Sound of Music Rodgersa i Hammersteina) (Sloboda, 2002, s. 307).
\end{abstract}

Nazwy solmizacyjne wywodzą się z tradycji kształcenia śpiewaków; kształcenie instrumentalistów wiąże się z kolei zazwyczaj z alfabetem muzycznym, w którym wykorzystywane są litery: $c, d, e, f, g, a, h, c$. W szkolnym słowniku zostało wyjaśnione, że alfabet muzyczny „to litery łacińskie użyte do oznaczenia kolejnych dźwięków skali diatonicznej: $a, b, c, d, e, f, g, h$. W teorii muzyki nowożytnej za punkt wyjścia skali oktawowej przyjęto dźwięk $c$ i zmieniono kolejność dźwięków: $c, d, e, f, g, a, h$ ( $h$ jako dźwięk wyższy o półton od $b$ )" (Poniatowska, 1997, s. 9). Warto zaznaczyć, że w krajach anglosaskich używa się litery $b$, która jest odpowiednikiem stosowanej w notacji polskiej nazwy $h$ (jest ona także stosowana w Niemczech) ${ }^{1}$. „Alfabet muzyczny powtarza się we wszystkich oktawach skali, ale dla znaczenia różnicy rejestrów stosuje się duże i małe litery oraz cyfry [...]: oktawa wielka $C-H$, oktawa mała $c-h$, oktawa razkreślna $c^{1}-h^{1}$, oktawa dwukreślna $c^{2}-h^{2}$, oktawa trzykreślna $c^{3}-h^{3}[\ldots]$ ". (tamże). Znajomość alfabetu muzycznego i umiejętność jego odczytywania głosem lub instrumentem pozwala pełniej uczestniczyć w kulturze muzycznej i z tego powodu są to umiejętności sygnalizowane $\mathrm{w}$ podstawie programowej dla klas I-III.

\footnotetext{
${ }^{1}$ https://happynote.com/music/music-theory-name-notes/
} 


\section{Nabywanie kompetencji muzycznych w zakresie notacji w świetle opinii psychologów}

We współczesnei psychologii muzyki często podkreśla się analogię między poznawaniem języka ojczystego i języka muzycznego. J. Sloboda pisze:

Zanim dzieci zaczną uczyć się czytać, umieją już płynnie posługiwać się językiem. Takich osiągnięć w muzyce zwykle nie mają. Większość dzieci uczy się nowej umiejętności muzycznej, np. gry na instrumencie, równocześnie ze zdobywaniem umiejętności czytania z nut. Takie podwójne zadanie jest czasami ponad siły dziecka, dlatego niektóre $\mathrm{z}$ nich starają się ułatwić sobie zadanie przez jak najszybsze zapamiętanie nowego utworu. Wykonanie nie zależy wtedy od sprawnego czytania nut (Sloboda, 2002, s. 81).

W kontekście niniejszych słów warto zaznaczyć, że poznawanie języka muzyki jest analogiczne do uczenia się mowy ojczystej, a więc ważne jest osłuchiwanie się z brzmieniem muzyki i eksperymentowanie z jej elementami przez różne aktywności muzyczne - takie działanie stanowi etap przygotowawczy do podjęcia systematycznej edukacji muzycznej i wprowadzenia zapisu muzycznego.

Czytanie muzyki to nie tylko nazywanie nut, ale rozumienie języka muzycznego. Wiele uwagi tej kwestii poświęca E. E. Gordon:

Kiedy czytamy jakiś tekst, łączymy litery w ugrupowania, czyli słowa, aby odkryć ich znaczenie za pomocą języka. W taki sam sposób czytamy muzykę - łączymy nuty w ugrupowania, czyli motywy tonalne i rytmiczne - aby dojść do jej rozumienia. Podczas gdy jedni potrafią przeczytać motyw składający się z kilku nut, inni są w stanie jedynie nazwać poszczególne nuty (Gordon, 1999, s. 62).

\section{Autor ten podkreśla}

Umiejętność czytania i pisania muzyki to coś więcej niż tylko zdolność do czytania i pisania nut. Tak samo, jak umiejętność czytania i pisania w danym języku, zawiera w sobie zdolność do mówienia, słuchania, czytania i pisania ze zrozumieniem, tak samo umiejętność czytania i pisania muzyki łączy w sobie takie umiejętności, jak słuchanie i wykonywanie muzyki, czytanie z nut i zapisywanie muzyki ze zrozumieniem (s. 65).

Proces edukacji muzycznej nie może zatem zakończyć się na poznaniu nazw dźwięków, ale należy również zastosować tę wiedzę do różnych aktywności muzycznych, tj. do gry na instrumentach perkusyjnych i melodycznych, śpiewu, ruchu przy muzyce, zabaw muzyczno-ruchowych.

Warto pamiętać, że przy poznawaniu notacji muzycznej może pojawić się „poczucie natłoku wymagań, których w całości nie można spełnić, jest charakterystyczne dla początków uczenia się w każdej dziedzinie [...]. Poczucie to może wywołać zniechęcenie i spowodować, że uczący się zrezygnuje z wysiłków, zanim osiągnie jakikolwiek postęp. W szczęśliwym położeniu będzie ten, kto znajdzie odpowiednią strategię, przyjętą być może od dobrego nauczyciela czy 
z dobrego podręcznika, która pomoże mu pokonać ten blok. Polega to na rozbiciu złożonej umiejętności na mniejsze komponenty, które można przyswoić sobie krok po kroku [...]" (Sloboda, 2002, s. 265).

Sloboda podkreśla: „Im młodsze dziecko, tym trudniej będzie mu wymyślić i narzucić swój własny plan uczenia się" (tamże). W procesie edukacji muzycznej warto stosować nie tylko strategię operacyjną (której istotą jest naśladownictwo), ale przede wszystkim strategię problemową ${ }^{2}, \mathrm{w}$ której nauczyciel stwarza warunki do zabawowego, refleksyjnego i aktywnego zdobycia wiedzy na temat notacji muzycznej przez dzieci. Pomocne przy poznawaniu alfabetu muzycznego mogą okazać się techniki i prawa podwajające skuteczność uczenia proponowane przez G. A. Dudleya. Zajęcia, podczas których dzieci poznają alfabet muzyczny, powinny być interesujące, gdyż zainteresowanie „ma fundamentalne znacznie dla zdolności koncentracji. Zainteresowanie oznacza, że człowiek angażuje się w to, co robi [...]. Jest to proces psychiczny, w którym tworzy się poczucie bliskości z danym tematem, dzięki czemu uwaga kieruje się ku konkretnemu wrażeniu, wybierając je spośród wielu innych" (Dudley, 2001, s. 98-99). Według G. A. Dudleya kluczowe dla zapamiętywania są codzienne powtórzenia całości materiału, który został zrozumiany (s. 112-113). Istotne jest także powtarzanie materiału o stałej porze i w stałym miejscu (s. 127). Warto podkreślić, że po intensywnej nauce „odpoczynek i relaks pomoże nam lepiej zapamiętać przyswojony materiał. Najlepiej nie wykonywać wtedy innej pracy umysłowej, zwłaszcza o podobnym charakterze. Kilka minut rozluźnienia po nauce sprzyja utrwaleniu przyswojonego materiału bardziej niż dalsza wytężona aktywność umysłowa" (s. 139). W kontekście edukacji wczesnoszkolnej warto zapamiętać, aby podczas poznawania notacji muzycznej nie wprowadzać tego samego dnia nowych liter alfabetu języka ojczystego, zgodnie z postulatami psychologów kolejna aktywność powinna być odmienna. Ponadto istotne jest, aby trening odczytywania notacji muzycznej pojawiał się codziennie, a nie tylko okazjonalnie. Warto poświęcić codziennie tylko kilka minut na tę aktywność - dzieci mogą codziennie odczytywać po dwa takty piosenki (i grać fragment na dowolnym instrumencie melodycznym, a następnie próbować śpiewać fragment melodii), tak aby pod koniec tygodnia udało im się samodzielnie rozszyfrować całą piosenkę.

\section{Wybrane sposoby wprowadzania zapisu muzycznego}

Poznawanie zapisu muzycznego w klasach I-III powinno być poprzedzone licznymi doświadczeniami muzycznymi, tj. śpiewaniem piosenek, graniem na instrumentach perkusyjnych (melodycznych), słuchaniem muzyki, poruszaniem

\footnotetext{
${ }^{2}$ Szerzej na temat strategii: Goriszowski, Kowolik, 1994.
} 
Kształcenie słuchu i poznawanie zapisu dźwięków

\begin{tabular}{|c|c|}
\hline $\begin{array}{l}\text { Proponowane działania } \\
\text { wg Lipskiej i Przychodzińskiej } \\
\text { (1991, s. 239-250) }\end{array}$ & Komentarz metodyczny \\
\hline $\begin{array}{l}\text { Uwrażliwienie na dźwięki znacznie } \\
\text { różniące się wysokością, np. wysoki } \\
\text { i niski rejestr fortepianu - dźwię- } \\
\text { ki wysokie, niskie (s. 239) }\end{array}$ & \multirow{2}{*}{$\begin{array}{l}\text { Dźwięki trzech rejestrów fortepianu traktujemy m.in. jako } \\
\text { sygnały do wykonania umownego zadania, np. określonego } \\
\text { ruchu, zajęcia miejsca w sali. Stosujemy różne ćwiczenia } \\
\text { i zabawy (s. 239-240) }\end{array}$} \\
\hline $\begin{array}{l}\text { Uwrażliwienie na dźwięki z reje- } \\
\text { stru średniego (m.in. dźwięki } \\
\text { oktawy razkreślnej) - dźwięki } \\
\text { średnie (s. 239-240) }\end{array}$ & \\
\hline $\begin{array}{l}\text { „Uświadomienie dzieciom } \\
\text { kierunku linii melodycznej” } \\
\text { (s. 240) }\end{array}$ & $\begin{array}{l}\text { Kiedy gramy dźwięki coraz wyższe, melodia się wznosi, } \\
\text { kiedy gramy dźwięki coraz niższe, melodia opada (s. 240). } \\
\text { Dzieci ilustrują kierunek melodii ręką, motywy melodycz- } \\
\text { ne interpretują plastycznie, improwizują głosem lub } \\
\text { instrumentem melodię narysowaną na tablicy itp. } \\
\text { (s. } 240-242 \text { ) }\end{array}$ \\
\hline $\begin{array}{l}\text { „Rozróżnianie dźwięków w zakre- } \\
\text { sie oktawy razkreślnej” — dźwięki } \\
\text { wyższe, niższe (s. 240) }\end{array}$ & $\begin{array}{l}\text { jw.; gdy melodia porusza się sekundami, to „idzie”; gdy } \\
\text { postępuje trójdźwiękami, to „skacze”. W ćwiczeniach } \\
\text { przechodzimy od większych interwałów do sekundy małej. } \\
\text { W różnych działaniach analizujemy, porównujemy dźwięki } \\
\text { takie same i różne. Przykłładowo: do zabawy wybieramy } \\
\text { dwie lub trzy wysokości, dzieci określają wyższy i niższy } \\
\text { dźwięk; określamy najniższy i najwyższy dźwięk w piosen- } \\
\text { ce; obserwujemy zmiany w powtórzonej melodii (s. 240-242) }\end{array}$ \\
\hline $\begin{array}{l}\text { „Odczytywanie fragmentów } \\
\text { melodii głosem z zapisu nutowe- } \\
\text { go”. Melodie-wzory (s. 242). } \\
\text { „Posługiwanie się zapisem przy } \\
\text { grze na instrumentach” (s. 242) }\end{array}$ & $\begin{array}{l}\text { Wprowadzenie pięciolinii i klucza wiolinowego. Poznawa- } \\
\text { nie (osłuchiwanie, uświadamianie) i utrwalanie poznanych } \\
\text { dźwięków lub melodii-wzorów (np. nauczyciel śpiewa } \\
\text { melodię z tekstem, a dzieci powtarzają; nauczyciel śpiewa } \\
\text { pytania, a dzieci odpowiadają; nauczyciel śpiewa melodię } \\
\text { i pokazuje wysokość poszczególnych dźwięków, a dzieci } \\
\text { powtarzają; nauczyciel śpiewa melodię-wzór nazwami } \\
\text { solmizacyjnymi i z fonogestyką, dzieci natomiast powtarza- } \\
\text { ją; nauczyciel pokazuje położenie dźwięków na pięciolinii, } \\
\text { dzieci grają je na dzwonkach lub wykonują głosem) } \\
\text { (s. 244-246). } \\
\text { Wykorzystywanie poznanych dźwięków, melodii-wzorów } \\
\text { do sygnałów muzycznych, zabaw, akompaniamentów, } \\
\text { umuzycznienia wierszyków, gry na instrumentach melo- } \\
\text { dycznych (s. 240-250). } \\
\text { Stopniowe poznawanie materiału dźwiękowego i przekształ- } \\
\text { canie go. Poznanie dźwięków skali durowej i charaktery- } \\
\text { stycznych zwrotów melodycznych. Poznanie nazw solmiza- } \\
\text { cyjnych, umieszczenie ich na pięciolinii (s. 239-250) }\end{array}$ \\
\hline
\end{tabular}


się do muzyki, wyrażaniem muzyki ruchem, gestem, słowem. Dziecko zatem eksploruje muzykę i eksperymentuje z nią. Dopiero na kanwie bogatych doświadczeń muzycznych powinien być wprowadzany zapis muzyczny, łączony z grą na instrumentach, takich jak dzwonki chromatyczne, Bum Bum Rurki. Przykładowo: M. Przychodzińska (Lipska, Przychodzińska, 1991) łączy wprowadzanie zapisu nutowego z kształceniem świadomych wyobrażeń muzycznych w zakresie wysokości dźwięków.

Naukę ułatwiają różne rodzaje mnemoniki: układanie zdań z pierwszych liter, układanie akronimów, rymowanek, skojarzenia, gry słowne (Dudley, 2001, s. 174). Warto przy nauce alfabetu wykorzystywać skojarzenia. Takie zabiegi były stosowane od wieków, m.in. przez Tacyta czy Guida z Arezzo. Przykładowo w kulturze anglosaskiej: „Dziecko zaczynające grać na fortepianie, uczy się nazw dźwięków odpowiadających odstępom między liniami w kluczu wiolinowym, kojarząc je z literami słowa FACE [twarz]. Nazwy dźwięków odpowiadających liniom w kluczu wiolinowym kojarzone są z pierwszymi literami słów w zdaniu: Every Good Boy Deserves Fan [Każdy grzeczny chłopiec zasługuje na zabawę]" (s. 162-163). Wydaje się, że w kulturze polskiej nie jest to tak popularne ćwiczenie, więc proponuję, aby każdy nauczyciel wraz z uczniami ułożył propozycję zdania, którego kolejne wyrazy będą rozpoczynać się od liter $e^{1}, g^{1}$, $h^{1}, d^{2}, f^{2}$. Ustalona propozycja powinna być zapamiętana i konsekwencje stosowana przy różnych zabawach, dzięki czemu dzieci będą kojarzyć przypisaną nazwę linii $z$ wyrazem. Przykładowe propozycje zdań utrwalających nazwy poszczególnych linii w kluczu wiolinowym:

Echo gra hejnał dla farmera.

Ewa gna hulajnogą do filharmonii.

Ekierka gotuje homara dla foki.

\begin{tabular}{|l|c|c|c|c|}
\hline \multirow{2}{*}{$\begin{array}{l}\text { Położenie linii } \\
\text { w kluczu wiolinowym }\end{array}$} & \multirow{2}{*}{$\begin{array}{l}\text { Odpowiadająca } \\
\text { nazwa literowa }\end{array}$} & \multicolumn{3}{|c|}{ Przypisany wyraz } \\
\cline { 3 - 5 } & & Wariant 1 & Wariant 2 & Wariant 3 \\
\hline Pierwsza linia od dołu & $e^{1}$ & Echo & Ewa & Ekierka \\
\hline Druga linia od dołu & $g^{1}$ & Gra & Gna & Gotuje \\
\hline Trzecia linia od dołu & $h^{1}$ & Hejnał & Hulajnogą & Homara \\
\hline Czwarta linia od dołu & $d^{2}$ & Dla & Do & Dla \\
\hline Piąta linia & $f^{2}$ & Farmera. & Filharmonii. & Foki. \\
\hline
\end{tabular}

Opracowanie własne. 
Pięciolinia na podłodze. Podczas przeglądania różnych środków dydaktycznych stwierdziłam, że przy niewielkim nakładzie kosztów każdy nauczyciel może wykonać interesującą pomoc do zajęć muzycznych przy użyciu taśmy malarskiej ${ }^{3}$, którą wyklei pięciolinię na podłodze. Ważne, aby w odpowiednim miejscu zaznaczyć także klucz wiolinowy (powinien mieć początek na drugiej linii od dołu). Przy wprowadzeniu pięciolinii należy dzieciom zwrócić uwagę, że linie i pola liczymy od dołu — jest to kluczowa umowa między dziećmi i nauczycielem. Jej konsekwentne przestrzeganie ułatwi komunikację i określanie położenia dźwięków. Wielka pięciolinia może służyć dzieciom do wspólnego zapisywania prostych piosenek, melodii-wzorów, układania melodii. Na tak dużej pięciolinii ośmioro dzieci może równocześnie zajmować miejsca poszczególnych dźwięków gamy. Proponuję zabawę, w której każde dziecko losuje etykietkę zawierającą jedną $\mathrm{z}$ liter alfabetu muzycznego: $c^{1}, d^{1}, e^{1}, f^{1}, g^{1}, a^{1}, h^{1}, c^{2}$, a następnie zajmuje właściwe miejsce na dużej pięciolinii i opisuje swoje położenie.

\begin{tabular}{|c|l|}
\hline Nazwa literowa & Określenie położenia na pięciolinii \\
\hline$c^{1}$ & Stoję na pierwszej dodanej linii dolnej \\
\hline$d^{1}$ & Stoję pod pierwszą linią \\
\hline$e^{1}$ & Stoję na pierwszej linii \\
\hline$f^{1}$ & Stoję na pierwszym polu \\
\hline$g^{1}$ & Stoję na drugiej linii \\
\hline$a^{1}$ & Stoję na drugim polu \\
\hline$h^{1}$ & Stoję na trzeciej linii \\
\hline$c^{2}$ & Stoję na trzecim polu \\
\hline
\end{tabular}

Ćwiczenia uwrażliwiające na kierunek linii melodycznej są szczególnie pożądane $\mathrm{w}$ fazie przygotowania do zapisu muzycznego. Popularne w pracy nauczyciela są karty pracy. Stosunkowo łatwo można wykonać powiększoną pięciolinię, na której dzieci mogą układać różne niewielkie przedmioty, wskazywać palcem położenie dźwięków.

W kolejnym ćwiczeniu dzieci ilustrują ruchem kierunek linii melodycznej, można wykorzystać do niego poniższe śpiewanki stanowiące połączenie gamy wraz $\mathrm{z}$ instrukcją słowną:

${ }^{3}$ Pomysł ten nie jest nowy i był on już proponowany jako zabawa polisensoryczna w kilku przedszkolach. Na przygotowanej w ten sposób pięciolinii układano piłki sensoryczne, po których dzieci się poruszały (https://przedszkole8.przedszkolowo.pl/strefa-nauczyciela/relacje,do-re-mi-fasol-la-si-dosensoryczna-pieciolinia-u-misiakow,166356?photo=4\#photo; http://ps3.kielce.eu/zawartosc/zabawy-na-pieciolinii). 
Moje ręce idą w górę

słowa i muzyka: J. Szczyrba-Poroszewska

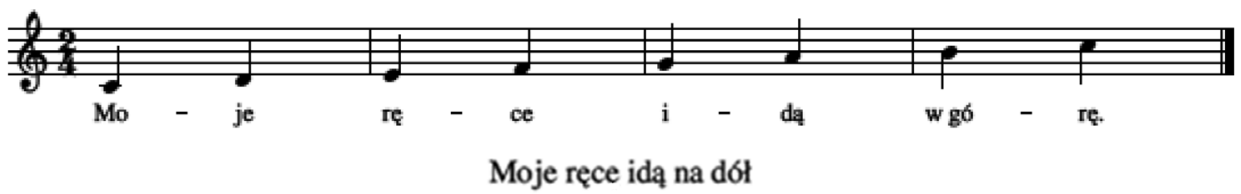

slowa i muzyka: J. Szczyrba-Poroszewska

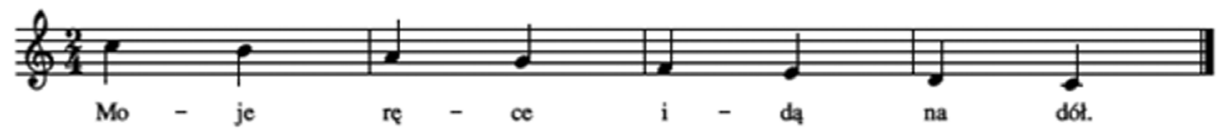

Ponadto dzieci mogą otrzymać powiększone nuty piosenki i pokazywać właściwy przykład melodyczny w zależności od tego, który w tym momencie wykonuje nauczyciel, mogą połączyć także linią główki nut. Praktyka edukacyjna pokazuje, że dzieci akceptują zabawę, a $z$ czasem $z$ własnej inicjatywy włączają się także do śpiewania. Ponadto zaobserwowano, że dzieci spontanicznie dodają te słowa do gam realizowanych na instrumentach. Śpiewankę można wykonywać głosem, a także łączyć ją z brzmieniem innych instrumentów, np. dzwonków, Bum Bum Rurek, fortepianu. Realizowanie gamy na flecie w początkowym stadium nauki nie jest wskazane, ponieważ dźwięk $c^{1}$ jest dźwiękiem trudnym do uzyskania na tym instrumencie, co może zniechęcić dzieci do nauki gry (poprawnie metodycznie jest zaczynać grę na flecie od lewej ręki i od dźwięków $g^{1}-h^{1}$; por. Lipska, Przychodzińska, 1991, s. 102-115).

Dużą popularnością cieszą się aktualnie Bum Bum Rurki, które można wykorzystać do praktycznej nauki czytania nut. Każda rurka oznaczona jest nie tylko kolorem, ale zwykle zaopatrzona jest także w naklejkę $\mathrm{z}$ zapisem literowym i solmizacyjnym dźwięku. Analiza różnych materiałów wskazuje, że wprowadzenie Bum Bum Rurek jest możliwe m.in. przez wykorzystanie kolorowej notacji. Za optymalny uznaję jednak tradycyjny zapis literowy — w taki sposób jest zanotowana większość muzyki instrumentalnej oraz śpiewniki. I o ile istnieje wiele piosenek oswajających $\mathrm{z}$ nazwami solmizacyjnymi ${ }^{4}$, o tyle nazwy literowe są $w$ piosenkach rzadziej wprowadzane. Aby świadomie grać na Bum

${ }^{4}$ Przykładowo Sound of Music (https://www.youtube.com/watch?v=drnBMAEA3AM) jest bardzo znaną piosenką popularyzującą sylaby solmizacyjne, jest ona znana w wieku krajach, doczekała także polskich adaptacji (https://www.youtube.com/watch?v=lxv0O10Tvb4). Sylaby solmizacyjne są także propagowane w m.in. w piosence Polka fasolka (https://www.youtube.com/watch?v=1F8dOi29h0o) i innych autorskich piosenkach (https://www.youtube.com/watch?v=a0OjO8A23Iw). 
Dzisiaj dobrze bawię się

słowa i muzyka: J. Szczyrba-Poroszewska
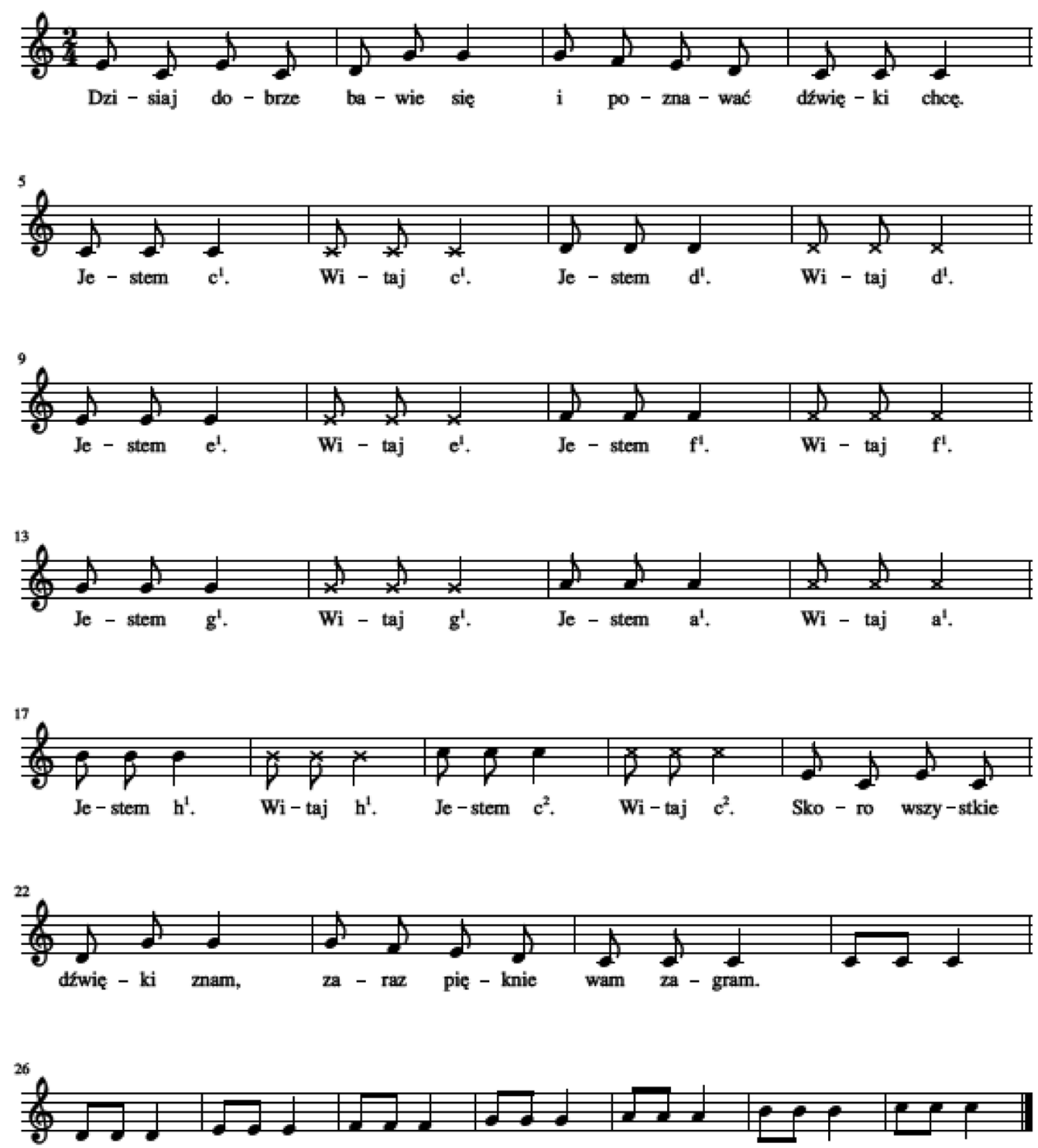

Bum Rurkach z wykorzystaniem notacji literowej, proponuję następującą kolejność działań:

— każde z dzieci wybiera jedną Bum Bum Rurkę;

- dzieci otrzymują jedną minutę na eksperymentowanie z Bum Bum Rurką (różne sposoby wydobywania dźwięku, próba intonowania dźwięku, jaki wydaje instrument); 
— dzieci maszerują do muzyki (https://www.youtube.com/watch? v=y3i2YuMlN7c); na przerwę w muzyce ustawiają się w kolejności od najdłuższej do najkrótszej Bum Bum Rurki (wykorzystujemy rurki tworzące gamę $C$-dur: $c^{1}$, $\left.d^{1}, e^{1}, f^{1}, g^{1}, a^{1}, h^{1}, c^{2}\right)$

- każde $z$ dzieci sprawdza i odczytuje, jaka litera alfabetu została przypisana jego rurce;

- muzyczna zabawa z piosenką Dzisiaj dobrze bawię się. Nauczyciel śpiewa piosenkę, podczas której prezentowane i witane są poszczególne litery alfabetu muzycznego: na słowie "Jestem" włącza się dziecko rytmiczną grą na odpowiedniej Bum Bum Rurce; pozostałe dzieci odpowiadają: „Witaj” — zależnie od możliwości dzieci powitanie może być rytmicznie wypowiedziane lub zaśpiewane; przy kolejnym wykonaniu piosenki dzieci podają własne określenia dźwięku, który został im przydzielony, np. całuje $c^{1}$, dobre $d^{1}$, eleganckie $e^{1}$, fajne $f^{1}$, górskie $g^{1}$, aktywne $a^{1}$, hulające $h^{1}$, całuje $c^{2}$. Istotne jest, aby określenia te zostały wykonane $\mathrm{w}$ metrum dwumiarowym, tak by zastąpić $\mathrm{w}$ piosence fragment „Jestem" zaproponowanym przez dzieci określeniem. Dzieci, które nie mają Bum Bum Rurki, powtarzają określenie i starają się je ilustrować ruchem. W ten sposób angażujemy wszystkie dzieci nawet przy niewielkiej liczbie instrumentów. Każde dziecko, które grało na Bum Bum Rurce, szuka swojej nuty na pięciolinii, określa jej położenie, a następnie zajmuje właściwe miejsce na pięciolinii wyklejonej na podłodze. Podczas kolejnego wykonania piosenki podskakują rytmicznie dzieci mające literę alfabetu muzycznego, o której śpiewa nauczyciel.

\section{Zakończenie}

W kontekście doniesień psychologów, a także doświadczeń pedagogicznych, warto podkreślić, że kształtowanie pojęć muzycznych i wprowadzanie notacji muzycznej powinno składać się z kilku etapów:

1. Etap przygotowawczy - dziecko zdobywa różne doświadczenia muzyczne na drodze akulturacji, przez słuchanie muzyki i eksperymentowanie m.in. z głosem, instrumentami, ciałem, przedmiotami codziennego użytku.

2. Wprowadzenie zapisu muzycznego - uczenie się przez działanie i zabawę, wykorzystanie mnemotechnik i instrumentów melodycznych, zagadek muzycznych, ćwiczeń inhibicyjno-incytacyjnych, przygotowanie do korzystania z zapisu muzycznego z wykorzystaniem metody problemowo-odtwórczej.

3. Utrwalenie - wielokrotne zabawowe i aktywne powtórzenia z wykorzystaniem różnych aktywności muzycznych, metody problemowo-odtwórczej (np. w zakresie nie całego utworu, ale kilku taktów), różnych środków dydaktycznych tradycyjnych (m.in. instrumentów, gier muzycznych, klocków i ko- 
stek muzycznych) oraz multimedialnych aż do ugruntowania znajomości zapisu i umiejętności posługiwania się nim w praktyce. Za praktyczną umiejętność uważam umiejętność gry na instrumencie melodycznym z nut (tradycyjnym lub wirtualnym).

Wprowadzenie zapisu jest ważnym krokiem prowadzącym do aktywnego uczestnictwa w kulturze muzycznej. Według psychologów warto poświęcać tej czynności codziennie kilka minut, warto także pamiętać, by tego dnia dzieci nie podejmowały podobnych działań, np. związanych z poznawaniem nowej litery alfabetu ojczystego. Aby proces poznawania zapisu muzycznego był efektywny i trwały, należy poświęcić wiele czasu na powtórzenie tego zagadnienia, najlepiej w różnych odsłonach. Ważne może okazać się wyznaczenie w sali odpowiedniego miejsca, które dzieci będą kojarzyć z sytuacją poznania zapisu muzycznego (Dudley, 2001).

\section{Bibliografia}

Dudley, G. A. (2001). Fak podwoić skuteczność uczenia się. Techniki sprawnego zapamiętywania i przywotywania informacji. Przeł. K. Doroszewska. [Warszawa]: Wyd. Medium.

Gordon, E. E. (1999). Sekwencje uczenia się w muzyce. Umiejętności, zawartości i motywy. Teoria uczenia się muzyki. Przeł. A. Zielińska-Croom, E. Klimas-Kuchtowa. Bydgoszcz: Wyd. Uczelniane WSP.

Goriszowski, W., Kowolik, P. (1994). Metodologiczno-metodyczne problemy wychowania muzycznego $w$ zarysie. Kielce: Wyd. Pedagogiczne ZNP.

Lipska, E., Przychodzińska, M. (1991). Muzyka w nauczaniu początkowym. Metodyka. Warszawa: WSiP.

Mała encyklopedia muzyki. (1968). Red. S. Śledziński. Warszawa: PWN.

Poniatowska, I. (1997). Stownik szkolny. Muzyka. Warszawa: WSiP.

Sloboda, J. A. (2002). Umyst muzyczny. Poznawcza psychologia muzyki. Przeł. A. Białkowski, E. Klimas-Kuchtowa, A. Urban. Warszawa: AM.

\section{Netografia}

http://ps3.kielce.eu/zawartosc/zabawy-na-pieciolinii https://happynote.com/music/music-theory-name-notes/

https://przedszkole8.przedszkolowo.pl/strefa-nauczyciela/relacje,do-re-mi-fa-sol-la-si-dosensorycz-

na-pieciolinia-u-misiakow, 166356 ?photo $=4 \#$ photo

https://www.youtube.com/watch?v=1F8dOi29h0o

https://www.youtube.com/watch? $\mathrm{v}=\mathrm{a} 0 \mathrm{OjO} 08 \mathrm{~A} 23 \mathrm{Iw}$

$\mathrm{https}: / /$ www.youtube.com/watch?v=drnBMAEA3AM

https://www.youtube.com/watch?v =lxv0O10Tvb4 
